\title{
HOW SUCCESSFUL WAS JOSEPH STALIN IN ESTABLISHING THE SOVIET UNION AS A SUPERPOWER?
}

\author{
JAKUB MAJKOWSKI \\ Faculty of Letters, University of Wrocław, \\ pl. Uniwersytecki 1, 50-137 Wrocław \\ E-mail address: majkow@autograf.pl
}

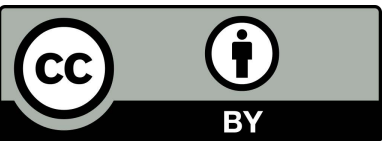

\section{ABSTRACT}

This essay will firstly address the extent of Joseph Stalin's achievements in leading the course for domestic policy of the Soviet Union and its contribution towards maintaining the country's supremacy in the world, for example the rapid post-war recovery of industry and agriculture, and secondly, the foreign policy including ambiguous relations with Communist governments of countries forming the Eastern Bloc, maintaining frail alliances and growing antagonism towards western powers, especially the United States of America.

The actions and influence of J. Stalin's closest associates in the Communist Party and the effect of Soviet propaganda on the society are also reviewed. This investigation will cover the period from 1945 to 1953. Additionally, other factors such as the impact of a post-war worldwide economic situation and attitude of the society of the Soviet Union will be discussed.

Key words: Soviet Union, Communism, Stalin, World War, superpower

\section{INTRODUCTION}

The reign of Joseph Stalin remains a controversial topic in Russia. Although Nikita Krushchev's de-Stalinization of the Soviet Union revealed the extent of atrocities inflicted by the deceased leader on the society, such as the Great Purge of the Communist Party and renowned military officials, nationwide Gulag camps, forced resettlement of the population or numerous massacres of civilians, the fact that under J. Stalin's reign the Soviet Union rose to power greater than even that of the Russian Empire at its peak cannot be denied. For a technologically backward country torn by revolution and a civil war, to defeat the militarist state of Nazi Germany and rise to the rank of a superpower is truly an outstanding feat. However, does it justify the death of approximately 20 million people?

While retaining an image of a ruthless tyrant in the West, J. Stalin retains certain popularity in Eastern Europe. In fact, Russia has recently experienced a rise in popularity of J. Stalin. According to an independent poll conducted 
in 2016, about $34 \%$ of the respondents claimed that "leading the Soviet people to victory in the Second World War was such a great achievement that it outweighed the Soviet dictator's vices and mistakes" (Public opinion of Stalin improves over past few years - poll results, 2016). Could such a stance be a remnant of J. Stalin's notorious cult of personality after over half a century, a certain sentiment of the people towards a strong-arm régime or perhaps even a superiority of an authoritarian rule over democracy?

In order to find an answer to those questions, we need to examine the role this de facto dictator played in bringing about the supremacy of the Soviet Union in Europe and evaluate the methods he used, as well as their result.

\section{DOMESTIC POLICY: THE THREAT OF STALIN'S REIGN AND CONSOLIDATING POWER WITHIN THE PARTY}

The defeat of the Axis powers on 9 May 1945 was a pyrrhic victory for the Soviet Union. The total losses, encompassing approximately over $10.7 \mathrm{mln}$ military and 15.9 mln civilian deaths (Erlikman, 2004, pp. 23-25), left the state in economic disarray. The Soviet Union lost about $25 \%$ of its resources from before the war; about 70 thousand cities, towns and villages were destroyed, causing GDP to fall by about 34\% (Curtis, 1996; Roberts, 2006, pp. 4-5). To restore the country, the Soviet Government sent a request for credits from Great Britain and Sweden (Triska, \& Slusser, 1962, pp. 144-145), but refused economic aid offered by the United States of America which came to be known as the Marshall Plan. Instead, it decided to rely on newly Soviet-occupied Eastern Europe to provide it with necessary resources. How could such a weakened country not only survive without the support of economically superior capitalist states, but even emerge as a superpower to rival the United States?

In order to understand the methods and effects of domestic policy leading to the restoration of the Soviet Union, one needs to examine the way the Soviet Government worked.

Up until October 1945, a month after the Allied victory in the Second World War, Joseph Stalin had ruled the country in an authoritarian style. He controlled the development of the propaganda apparatus and his cult of personality, made final decisions regarding the Soviet Union's foreign policy, and most importantly, maintained strict control and surveillance over the Communist Party. However, he couldn't supervise every detail of ruling such a vast country - those lay in the hands of his group of henchmen: Lavrentiy Beria, Nikita Khrushchev, Anastas Mikoyan, Georgy Malenkov, Vyacheslav Molotov and Andrei Zhdanov. Despite the seeming cooperation between the men, they were all extremely distrustful towards each other, they were spying on each other and denouncing Stalin at every opportunity, while at the same time vying to take over his position as the supreme leader (Montefiore, 2003, pp. 277-286).

In October one of them, V. Molotov, was for the first time given such a chance. The leader's physical health became increasingly worse - he already suf- 
fered a mild stroke in June, but in October the symptoms returned and Stalin had a heart attack. After the attack, V. Molotov, G. Malenkov and the leader himself jointly agreed that he needed a vacation to alleviate stress. On 9 October he left for Gagra in Abkhazia and would stay there for one and a half months. During his absence the country was ruled by V. Molotov, the Minister of Foreign Affairs at the time, whom J. Stalin chose as the First Deputy for this period, but obligated to heed assistance of the other henchmen. The power was split, but the atmosphere of this new reign was in fact little different from Stalin's terror. The prospect of consequences for defying Stalin's orders was actually the only thing keeping V. Molotov's 'assistants' from dethroning him (Montefiore, 2003, pp. 546-565). The threat of the collapse of power in the Soviet Union escalated further when the information about the leader's heart attack was leaked to both western and national newspapers, which spread rumors about his 'inability to rule'. This problem however did not go unnoticed by J. Stalin. In order to undermine the rumors and find the perpetrators, J. Stalin felt the need to exert more control over the Politburo from afar. As he kept confronting V. Molotov about his decisions, the tension between J. Stalin and V. Molotov, his second-in-command, rose. The largest difference between them was in their attitude towards the Western powers behind the Iron Curtain. While V. Molotov was more liberal and eager to secure an alliance with the West, Stalin had conservative views and wanted to "break the façade of friendly relations" with the United States. After V. Molotov on 7 November suggested an alleviation of censorship on foreign newspapers, J. Stalin decided to remove him from power. He found an excuse to do so when New York Times wrote an article about J. Stalin's alleged sickness (Montefiore, 2003, pp. 568-575). Although the western newspapers had written about J. Stalin's heart attack before, this time the leader blamed V. Molotov directly for the leakage and ordered an investigation on his part in this endeavor. Unsurprisingly, the evidence for V. Molotov's mistake was found. The deputy General Secretary was interrogated by his closest comrades - L. Beria, Malenkov and Mikoyan. He admitted to all charges and sent a letter to J. Stalin in which he begged for mercy and a chance at redemption. On 8 December J. Stalin returned V. Molotov to his previous position of a First Deputy Premier.

J. Stalin had now returned with full strength to defeat the other two main claimants to the Soviet Throne: L. Beria and G. Malenkov.

The perks of L. Beria - decisiveness when facing any problem, independence from other 'old-time' members of the Party, cunning in plotting with and against his comrades and his utter ruthlessness in dealing with 'enemies of the state' - ensured his unofficial succession of Nikolai Ezhov as a chief of NKVD during the Great Purge of 1938. G. Malenkov, on the other hand, won J. Stalin's favour through his unwavering loyalty during the Great Purge, as well as obediently discrediting Soviet war hero Georgy Zhukov. In both cases it was only a small mistake which ruined their reputation and ultimately resulted in their downfall (Montefiore, 2003, pp. 575-591).

On Stalin's time in Abkhazia the leader began to look at the losses of the Soviet Union from the Great Patriotic War. When he learned from his son, 
Vasili, that $47 \%$ of the air force losses were caused by planes' malfunction and not the enemy fire, he used it to undermine the leadership of Beria who appointed new air force officers after the purge of 1941, as well as G. Malenkov who was responsible for the production of planes (Montefiore, 2003, pp. 595-620).

Despite J. Stalin's health problems and conflicts with his most influential henchmen - V. Molotov, L. Beria and G. Malenkov - the leader was able to emerge victorious and once again consolidate power within the Communist Party in October 1945.

\section{FOREIGN POLICY: ESTABLISHMENT OF THE EASTERN BLOC}

The Potsdam Conference that took place from July to August 1945 was the last meeting of the leaders of three Great Powers at the time: the Soviet Union, the United States of America and Great Britain. Although the war was a month from being over, the Allied leaders were already dividing the territories retaken from the withdrawing Axis Powers. Due to the fact that the Red Army forces steadily advanced on Germany, steadily pushing back the Wehrmacht from Eastern and Central Europe, J. Stalin revealed the intent to appoint local communist parties in those war-torn countries as the new ruling bodies, which would effectively transform said countries into Communist republics and therefore increase the Soviet sphere of influence over Europe (Roberts, 2006, pp. 274-278). This strategy was in hindsight one of the most subtle and efficient methods of ensuring the Soviet Union's dominance in Europe. While it is true that maintaining the Red Army's presence in the conquered territories would have given J. Stalin an opportunity to take possession of the countries' supply of heavy metals, allowing for an even faster economic recovery of the Soviet Union, it was a better choice to establish a network of satellite states which would rebuild after the losses from the war in a longer period of time. Because of that, the Soviet forces were no longer spread thin and the war veterans were allowed to return to their homeland where they would be praised for their service or disposed of, if the supreme leader was to deem them dangerous to his regime. Also, the initial financial fragility of the newly created communist states ensured their dependency on the Soviet Union and sustained J. Stalin's hegemony (Hardt \& Kaufman, 1995, p. 15).

The decision also had ideological grounds The Marxist-Leninist idea of world communism of Bolsheviks of old had finally become a reality under the rule of Joseph Stalin, as red banners flew over most of Europe and Asia.

However, F. Hirsch (2005, p. 212) remarks that in reality the Soviet Union can be defined as "a new type of modernizing state - an empire of nations". According to R. Hahnel and M. Albert (1981, 24-25), this new political body contradicts the Marxist-Leninist idea of democratic centralism, which should consist of "freedom of discussion" and "unity of action" because of the repressive nature of the said 'empire'. 
Nevertheless, as much as the Eastern Bloc strayed from the conventional ideology of worldwide communist revolution, its creation was undoubtedly the first step towards establishing the Soviet Union as a world power.

\section{RELATIONS WITH THE USA: STALIN'S REFUSAL OF THE MARSHALL PLAN}

Despite the gradually apparent differences between the Western and Eastern Blocs, there was one occasion by which the Iron Curtain possibly could have been lifted - the European Recovery Program initiated by the USA on 3 April 1948, widely known as the Marshall Plan. The financial aid of approximately $\$ 13$ bn was proposed to the whole of Europe, but was ultimately rejected by Stalin. A decision to which the Soviet Union as well as all Communist governments in the Soviet Bloc had to adhere (Wettig, 2008, p. 149). G. Wettig (2008, p. 151) also mentions that "although Soviet refusal was perfectly reasonable, it was one of the key causes of the increase in tension between the opposing blocs which was the prelude of Cold War". One of the reasons for the Soviet decline of the offer was the Truman Doctrine, a newly introduced American anti-Soviet policy on 12 March 1947 (only a year before the initiation of the Marshall Plan). The policy meant to combat the influence of the Soviet Union in non-Soviet countries. In light of this aggressive stance of the United States, a suddenly generous proposal of a financial aid from the same country seemed at the very least suspicious to the Soviet Government which, after postponing the negotiations by six weeks, ultimately rejected every proposal given by the American and British governments.

Was J. Stalin's fear justified or did he miss an opportunity to greatly improve the Soviet Union's finances?

According to N. Chomsky and G. Ruggiero, the Marshall Plan's true goal was, contrary to the official statement of the USA, not only to improve trade with Europe and modernize industry, but also to hamper the spread of communism around the world by improving the financial situation of poor Eastern European states and therefore eliminate their dependency on the Soviet Union (Chomsky, \& Ruggiero, 2002, pp. 127-128). Therefore in hindsight J. Stalin's refusal was a reasonable choice in order to maintain the status of the Soviet Union as a superpower.

However, the rejection of Marshall Plan was not unanimous, as the Polish People's Republic, Hungarian People's Republic and Czechoslovak Socialist Republic still expressed interest in accepting the aid. Stalin reacted by forbidding the representatives of those countries from participating in the conference on the European Recovery Program in Paris. In the end those countries reluctantly rejected the Marshall Plan (Bideleux, \& Jeffries, 1998, pp. 202-203).

Such a blatant show of dominance of J. Stalin over the Eastern European states resulted in an increase of tension and gave voice to the opposition move- 
ments in those countries. Therefore we can say that although J. Stalin's choice was reasonable, the execution of it left much to be desired and resulted in a deterioration in the Soviet's Union relationship with both Western powers and the Eastern Bloc.

\section{RELATIONS WITH CHINA: STALIN'S SIGNING OF THE SINO-SOVIET TREATY OF FRIENDSHIP AND ALLIANCE}

The Sino-Soviet Treaty of Friendship, Alliance and Mutual Assistance was objectively the most beneficial alliance in Soviet Union's foreign policy on the Asian side. It increased the safety of the southern border and reduced the threat from Japan which was under heavy influence of the United States after the latter's victory in the Pacific War. It also allowed Soviet Union and People's republic of China to collectively support North Korea in the Korean War of 1950-53.

The relationship between J. Stalin and Mao Tse-Tung, however, lacked the eponymous friendship. During the Chinese Civil War from 1927-36 the Red Army offered only small assistance to Mao's insurgents who were heavily outnumbered by Kuomintang. Mao also still remembered the Sino-Soviet Non-Aggression Pact in 1937, back when there was still a Republic of China. The Soviet side broke the pact by assisting a Chinese warlord, Sheng Shicai, which led to Xinjiang War the same year. J. Stalin found the rising cult of Mao as a representative figure of Communist revolution to be dangerous to him. As for the ideological differences, Mao rightly presented the peasants as a class which perpetrated the revolution, instead of the workers. As this view contradicted the Marxist-Leninist idea of workers as the main revolutionary group, J. Stalin was antagonistic towards the Maoist ideology (Montefiore, 2003, pp. 425-434)

Nevertheless, the treaty was signed by both parties and lasted for ten years until Sino-Soviet Split during Khrushchev's rule. Although, according to Kuisong, "China's claims far outran the expectations of the Soviet side". They demanded that Soviet Union renounce the lease of Port Lüshun as a naval base and return that privilege to China, release the hold of Changchun Railway and the city of Dalian. The Soviet side in exchange called for lifting taxation on raw materials transported through the Changchun Railway for three years (Kuisong, 2005, p. 7). The Chinese had clear advantage with these conditions, but J. Stalin decided to sign the document regardless.

While the alliance was not a diplomatic victory of J. Stalin by a large margin, it provided Soviet Union with a very strong ally in Asia. J. Stalin can the very least be credited for maintaining the fragile alliance which ensured cooperation between the superpowers up until the Sino-Soviet Split in 1960, seven years after J. Stalin's death. 


\section{FOREIGN POLICY REGARDING THE EASTERN BLOC: CRE- ATION OF COMECON}

Despite J. Stalin's refusal to cooperate with Western powers, he was able to take note of their successful policies and introduce similar constructs. When the Organisation for European Economic Co-operation (OECC) was established on 16th April 1948 from the initiative of France to assist in the economic growth of member countries as part of the Marshall Plan, J. Stalin created the Council for Mutual Economic Assistance (Comecon) less than a year later, on 5th January 1949, out of concern of the Eastern Bloc's economy being susceptible to the Western influence. Alas, during J. Stalin's reign Comecon's role focused merely on transferring fuel and raw materials from the Soviet Union to Eastern Europe in exchange for services and machines created from the said materials. This process was due to the Eastern European technologically inferior factories and the need for larger amounts of fuel to run them. Additionally, in 1950 Joseph Stalin severely limited the duties of Comecon in favour of pursuing self-sufficiency of the Soviet Union. The reason for that, according to Brine, might be that the international aspect of Comecon made it hard to be controlled by the Soviet Union, so J. Stalin decided to revert to the traditional way of the Soviet Union lending aid to its satellite states. The Council for Mutual Economic Assistance wouldn't have an important role in the Eastern Bloc until after J. Stalin died and N. Khruschev took over (Brine, 1992, pp. 120-122).

This makes Comecon a failure of J. Stalin, especially compared to the success of OECC on the other side of the Iron Curtain.

\section{TITO-STALIN SPLIT}

Without doubt the dictator's greatest political failure was the Tito-Stalin Split in 1948, which came to the surprise of diplomats in both Western Europe and the Eastern Bloc, since Yugoslavia was considered the Soviet Union's most loyal ally among communist states, even despite the minuscule assistance of the Red Army in Josip Broz Tito's liberation of Yugoslavia from the Axis powers in 1945.

Officially Cominform accused the Yugoslavs of disobeying the Marxist-Leninist system and pursuing their own version of socialism on 28 June 1948. However, Yugoslavia's political system was no more anti-marxist than for example Poland's as Cominform had noted in a memorandum sent to Mikhail Suslov, member of the Central Committee. And yet only Yugoslavia faced expulsion from the Cominform. In truth J. B. Tito's loyalty did not prevent him from strengthening the country by capturing Istria a region that had belonged to Italy before Mussolini's defeat. J. B. Tito was also planning to gain Trieste, but J. Stalin, as well as the West, opposed this idea because of the region's role in trade between Eastern and Central Europe. The Yugoslavian government also supported the Greek Communist Party in the Greek Civil War of 1946-49 as a way to create its own sphere of influence (Laković \& Tasić, 2016, pp. 52-60). 
The threat of Yugoslavia becoming a rival major power in the Eastern Bloc made Stalin expel the country from Cominform. This move contributed to the weakening of Yugoslavia's foreign trade and by extension prevented J. B. Tito from sending greater aid to Greek communists and their loss in the civil war. On the other hand, it was the intervention of the USA that ultimately sealed the victory of the Hellenic Army, which means that J. Stalin's power might have not been endangered by J. B. Tito at all, had he not rejected Yugoslavia. Additionally, J. B. Tito's departure was portrayed in Yugoslavia and the West as an act of patriotism and independence, which enforced J. B. Tito's cult of personality and undermined the Soviet Union's hegemony (Laković \& Tasić, 2016, pp. 62-65)

It is still not certain whether the Tito-Stalin split was unavoidable. Perhaps the Soviet Union's constant demands for raw materials and blatant intrusion into Yugoslav politics were too harsh for such a strong country and J. Stalin should have taken a different approach towards it than war-torn countries like e. g. Poland, but it is also possible that J. B. Tito would have risen in power either way. Nevertheless, J. Stalin's decision resulted in the loss of his greatest ally apart from China and contributed to the loss of communists in the Greek Civil War, expanding the influence of the USA.

\section{CONCLUSION}

Joseph Stalin laid the groundwork for the Soviet Union's road to become a superpower. He was very successful in directing domestic policy and preventing a split in the Communist Party. His use of terror, albeit resulting in a great loss of human life, was beneficial for the country's economy and industry. On the other hand, his method of silencing the opposition both inside and outside of the party and the cult of personality built around him resulted in J. Stalin being irreplaceable and thus, after his eventual death, binding the next leader to have less power and appear weaker.

He had little success in foreign policy, with his greatest failures being the Tito-Stalin Split and, in the long run, the pressure he put on the Eastern Bloc, limiting Eastern Europe's technological development. However, in spite of his unsubtle relations with the satellite states and allies, he firmly held the Soviet Union's hegemony up until his death.

Based on this evidence we can state that Joseph Stalin was only partly successful in establishing the Soviet Union as a world power, being a strong ruler within the borders, but lacking in diplomatic skills in foreign affairs. He ultimately created a superpower, but one with inherent flaws - relying on terror and propaganda in the Soviet society and deliberate weakening of the economies of satellite states, in order to maintain control over them. 


\section{REFERENCES}

[1] Albert, M., Hahnel, R. (1981). Socialism today and tomorrow. Boston: South End Press.

[2] Bideleux, R., Jeffries, I. (1998). A History of Eastern Europe: Crisis and Change. London: Routledge.

[3] Brine, J. (1992). Comecon: The Rise and Fall of an International Socialist Organization. Birmingham: Transaction Publishers.

[4] Chomsky, N., Ruggiero, G. (2002). The Umbrella of U. S. Power: The Universal Declaration of Human Rights and the contradictions of U. S. policy. New York: Seven Stories Press.

[5] Curtis, G. (1996). Reconstruction and Cold War. Retrieved from: http://countrystudies.us/ russia/12.htm.

[6] Erlikman, V. (2004). Poteri narodonaseleniia v XX veke: spravochnik. [Population losses in the 20th century: a handbook.] Moscow: Russkaia panorama.

[7] Hardt, J., Kaufman, R. (1995). East-Central European Economies in Transition. New York: M. E. Sharpe.

[8] Hirsch, F. (2005). Empire of Nations: Etnographic Knowledge and the Making of the Soviet Union. Ithaca: Cornell University Press.

[9] Kuisong, Y. (2005) The Sino-Soviet Alliance and Nationalism: A Contradiction. Retrieved from: http://www.php.isn.ethz.ch/publications/areastudies/documents/sinosov/Kuisong. pdf.

[10] Laković, I., Tasić, D. (2016). The Tito-Stalin Split and Yugoslavia's Military Opening toward the West, 1950-1954: In NATO's Backyard. Lanham: Lexington Books.

[11] Montefiore, S. (2003). Stalin: The Court of the Red Tsar. London: Weidenfeld \& Nicolson Ltd.

[12] Public opinion of Stalin improves over past few years - poll results. (2016). Retrieved from: https:// www.rt.com/politics/328908-public-opinion-on-stalin-improves.

[13] Roberts, G. (2006). Stalin's Wars: From World War to Cold War, 1939-1953. Yale: Yale University Press.

[14] Triska, J., Slusser, R. (1962). The Theory, Law, and Policy of Soviet Treaties. Stanford: Stanford University Press.

[15] Wettig, G. (2008). Stalin and the Cold War. Plymouth: Rowman \& Littlefield Publishers, Inc. 